\title{
The RD\&I policy in Manaus Free Trade Zone: Opportunities and Challenges for the Implementation of the Industry 4.0
}

\author{
Armando Araújo de Souza Junior, Arthur de Freitas Lisboa, Luiz Frederico Oliveira de Aguiar, \\ Mauricio Itikawa, Ocileide Custódio da Silva and Sandro Breval Santiago
}

\section{ABSTRACT}

The paper aims to analyze the challenges and opportunities for the implementation of industry 4.0 from the perspective of a public policy to encourage research, development and innovation (RD\&I) from the Informatics Law (IL) in the Manaus Free Trade Zone (MFTZ). The theoretical foundation is initially carried out using the bibliographic and documental research method, based on a literature review on the main available knowledge scientific databases, using the terms "industry 4.0" and "research, development and innovation", as well as the IL RD\&I policy at MFTZ. The results are described in three dimensions: training and qualification of human resources, fostering the innovation ecosystem and RD\&I.

Keywords: Industry 4.0; Informatics Law; Manaus Free Trade Zone; Research, Development and Innovation.
Submitted : January 24, 2022

Published : February 15, 2022

ISSN: 2507-1076

DOI: $10.24018 /$ ejbmr.2022.7.1.1280

Armando Araújo de Souza Junior* Ph.D. Professor of Production Engineering, Postgraduate Program in Production Engineering, Federal University of Amazonas, Manaus, AM, Brazil.

(e-mail: armandoaraujo@ufam.edu.br) Arthur de Freitas Lisboa

Postgraduate Program in Production Engineering, Federal University of

Amazonas, Manaus, AM, Brazil.

(e-mail: arthur.lisboa@suframa.gov.br) Luiz Frederico Oliveira de Aguiar Postgraduate Program in Production Engineering, Federal University of

Amazonas, Manaus, AM, Brazil.

(e-mail: luiz.aguiar@suframa.gov.br) Maurício Itikawa

Postgraduate Program in Production Engineering, Federal University of Amazonas, Manaus, AM, Brazil. (e-mail:

mauricio.itikawa@suframa.gov.br) Ocileide Custodio da Silva

Ph.D. Professor of Production

Engineering, Postgraduate Program in Production Engineering, Federal University of Amazonas, Manaus, AM, Brazil.

(e-mail: ocileide@ufam.edu.br)

Sandro Breval Santiago

Ph.D. Professor of Production Engineering, Postgraduate Program in Production Engineering, Federal University of Amazonas, Manaus, AM, Brazil.

(e-mail: sbreval@gmail.com)

*Corresponding Author

\section{INTRODUCTION}

The fourth industrial revolution has made technological changes become faster, especially in the industry, where innovation and technological development are more intense and where this new technological period seems to start a cultural renaissance that may allow people to feel part of something much bigger - "a true global civilization." (Schwab, 2016).
The analysis of this article is based in this context of constant transformations, especially in the sense of identifying the opportunities and challenges for the implementation of important emerging Technologies in the MFTZ and its RD\&I based policy (Pereira; De Oliveira Simonetto, 2018)

A more in-depth analysis of the entire MFTZ RD\&I policy is then undertaken, through a documentary survey of the regulations established by the end of 2020, as well as reports and events that have been relevant to the development of 
industry 4.0 in the MFTZ. Finally, the opportunities and challenges for the materialization of initiatives aimed at industry 4.0 are presented.

This paper is divided into six sections. The first one presents the introduction of the study, then the theoretical framework that guided the study, presenting its central concepts. Furthermore, the methodology is presented, followed by the research results and the final considerations, ending with the references used.

\section{THEORETICAL FRAMEWORK}

From 2011, when the term industry 4.0 began to be used to synthesize the integration of information and communication technologies (ICT) that, together with organizational and cultural changes characterized the so-called fourth industrial revolution (Schuh et al., 2020), investments moved by different actors of the ecosystem began to be carried out in order to implement the digitalization of production processes, demanding innovations that oblige legislators to aim at modern public policies regarding innovation (Buhr, 2017).

In Brazil, more specifically in the MFTZ, this matter, although already regulated, is not mature, and, as it is still a technological frontier in terms of production systems, it must be related to innovation (Reischauer, 2018), often also linked to $\mathrm{R} \& \mathrm{D}$.

\section{A. Industry 4.0}

Understanding what industry 4.0 is about from the perspective of the fourth industrial revolution knowing the historical stages of the industry, each marked by technologies that identify each revolution stage (Fig. 1).

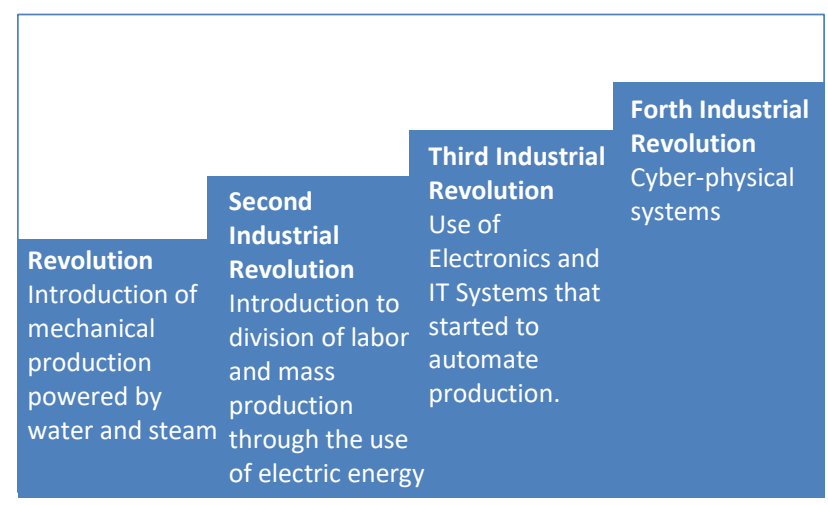

Fig. 1. Evolution of Industry through history.

The first industrial revolution was marked by the presence of steam engines at the end of the 18th century, followed by the second industrial revolution at the end of the 19th century, symbolized by the use of electric energy in mass production, notably by Fordism. The third industrial revolution took place in the mid-twentieth century with the introduction of microelectronics and industrial automation. Finally, the fourth industrial revolution, initiated in 2011 is marked by cyber-physical systems in manufacturing. (GTAI, 2014; Xu et al., 2018; Ghobakhloo, 2018; Reischauer, 2018).

GTAI (2014) defines cyber-physical systems as embedded technologies that bring together the virtual and real worlds in a single system in which intelligent objects interact with each other, being the basis of the Internet of Things (IoT), involving technologies that encloses data usage, internet, among others.

Furthermore, Reischauer (2018) and Etzkowitz (2003) postulated that industry 4.0 should be guided by a policy focused on innovation in a system known as the triple helix in which companies, research institutes and government are involved.

\section{B. Research, Development and Innovation}

Ferreira and Lisboa (2019) address different perspectives on innovation, demonstrating the breadth of the concept in current literature, presenting innovation as a source to foster economic growth cycles and competitive differentiation, which can be represented as a series of improvements in technology and in methods or ways of doing things.

According to the Data, I. I. (2005), R\&D comprises creative work carried out systematically with the greater purpose of increasing the existing stock of scientific and technological knowledge, including new applications for them. Closely connected concepts, investments in R\&D are active influencers in the search for technological innovation (Oliveira et al., 2015).

Oliveira et al (2015), when analyzing the panorama of R\&D investments in Brazil and the patent filings registered as measurement units of the impact of public and private investment in $R \& D$ obtained results favorable for the link between these expenditures and the increase of economic activity and innovation configured in increment of patent registration.

A report prepared by Firjan (2019), demonstrates that one of the four steps that industries must take towards industry 4.0 are investments in RD\&I, which shall provide essential competitive differentials in the era of industry 4.0, including through its association with startups. One of the governmental programs that positively influence the RD\&I ecosystem is the IL in the MFTZ.

\section{The politics of Research, Development and Innovation in the MFTZ}

Government intervention through public policies in the RD\&I ecosystem in the MFTZ region started with the publication of the Law $n^{\circ}$ 8.387, of December 30, 1991, which is the IL. In this sense, tax benefits were established and only companies that agree to invest in RD\&I are able to benefit from it (Law No. 8,387, 1991).

From Fig. 2, it is considered as "Calculation basis" the gross revenue related to the product usufruct of the benefit, deducting the taxes levied on marketing and the values of inputs also benefited by Law $n^{\circ} 8.387 / 1991$ or by Law $n^{\circ}$ $8.248 / 1991$ (IL applied to other regions of Brazil, excluding the area covered by the MFTZ).

The Fig. 3 illustrates the financial resources of the 5\% slice shown in figure 2 , which in the last five years covered by the data survey carried out by SUFRAMA (2020), more than R $\$$ 2.7 billion were invested in RD\&I in the western amazon states of Brazil and the state of Amapá.

It can be seen from Fig. 3 (SUFRAMA, 2021) that in the last 5 years, approximately three quarters of everything that was invested in RD\&I as a result of the IL was destined to the ICT accredited by CAPDA, the committee that was assigned to regulate RD\&I activities in the western amazon states of Brazil and the state of Amapá (Decree No. 10,521, 2020). 



RD\&I activities executed directly by the company

Technological projects with environment sustainability goals developed by entities accredited by CAPDA.

- Startup located in the Western Amazon /AP capitalization

Bioeconomic Social Organizations with management contract with Ministry of Economy.

CTI and Priority Programs accredited by CAPDA

Implementation or operation of enterprise incubator or accelerator accredited by CAPDA

Bioeconomic Social Organizations with management contract with Ministry of Economy.

$0,4 \%$ in Public ICT accredited by CAPDA (min)

$0,4 \%$ in Public ICT accredited by CAPDA (min)

$0,2 \%$ in Science and Technology Development National Fund (min)

Fig. 2. Investment in RD\&I - Mandatory by agent in the ecosystem (based on the IL).

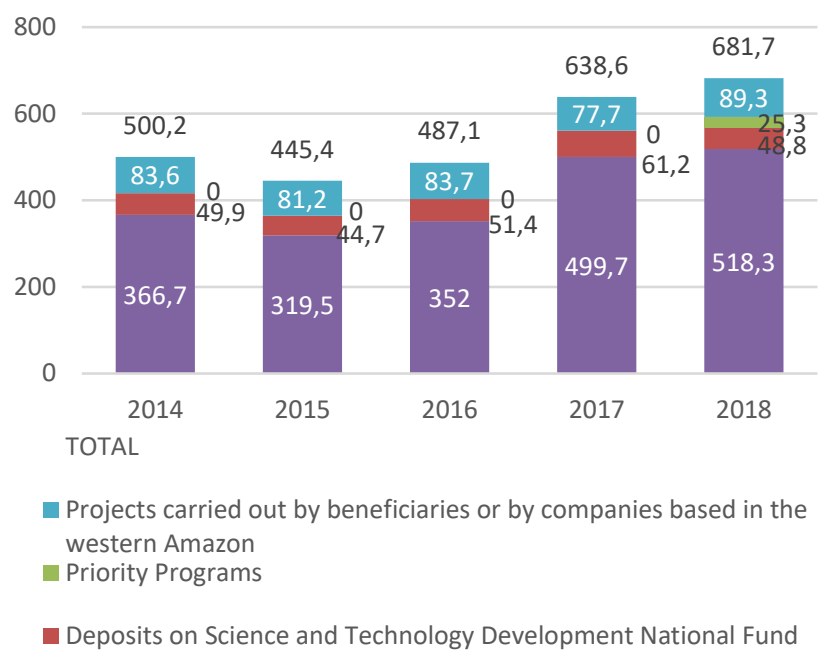

Fig. 3. Investments in RD\&I in MFTZ 2010 to 2018, R\$ x million. (Based in SUFRAMA, 2021).

The last amendment to the IL occurred in 2016, requiring new infralegal instruments that detail its content, when it was opportune to create the Ordinance $\mathrm{n}^{\circ} 2.091$, of December 2018, and Resolution $\mathrm{n}^{\circ}$ 40, of march 18, 2018, which explained the possibility of investing part of the annual obligation in the modernization of industrial parks in technologies aimed at industry 4.0. Finally, Decree $n^{\circ} 10.521$, of October 15, 2020, regulated the amended Law.

\section{Methodology}

This paper is initially characterized as descriptive research as it seeks to identify relation between variables (GIL, 2018, p.26), in these specific cases, between the public policy to encourage RD\&I in the IL of the MFTZ and industry 4.0.

As for the approach, this article deals with qualiquantitative research as it works with general concepts applied in standards, as well as seeking interpretations of numerical data obtained from the studied scenario. The quantitative approach is predominantly mathematical with data collection carried out systematically while the qualitative approach is characterized by being more interpretive and descriptive (Furtado, 2020, p. 187-188).

The research is explanatory in nature as to its purpose, since although it has a bibliographic-documentary-based approach, seeking to understand the relation based on a set of norms that have the IL in MFTZ and industry 4.0 at the edge, identify the challenges and opportunities that MFTZ has on the way to the modernization of its industrial park towards industry 4.0.

From the bibliographic and documentary survey, carried out through research in scientific databases and official documents prepared by representative entities of the industry and the government, a qualitative and quantitative analysis of the normative provisions allowed by the IL for the implementation of industry 4.0 was carried out at MFTZ.

\section{RESUlTS}

\section{A. Training and Qualification of Human Resources}

Buhr (2015) predicts that human work will not continue to be an important part of production but will become the central part of the decision-making process, or even responsible for the intelligent system to be built and managed. In this scenario, the aforementioned author predicts that nations whose workforce has less education will be the most sensitive to the implementation of technologies affected by Industry 4.0 due to the demand for qualification.

Considering the observation of Oliveira and Corrêa (2019) that the MFTZ industries still operate on Fordist/Taylorist bases with islands of technological sophistication, there is still a predominance of repetitive and massified jobs that do not require greater qualification of the employed labor, which is strong evidence that this region still has a great challenge in terms of having humans capable of leading the local industry to digital transformation.

As illustrated in Fig. 2, according to the IL, a minimum annual investment of $0.9 \%$ in ICT and $0.4 \%$ in public ICT is mandatory, both accredited by the CAPDA, and Decree No. $10.521 / 2020$, equals research institutions or higher education institutions maintained by the Public Power to ICT to comply with the aforementioned minimum percentages, as well as including as a RD\&I activity, professional education and training in areas considered priority by the same committee or involving basic, applied research, experimental development or technologic innovation.

From Fig. 3 it is possible to conclude that the average annual investments of the last 5 years of the data provided in SUFRAMA (2021) is approximately R $\$ 550$ million. Of these, is mandatory a minimum annual investment of $\mathrm{R} \$ 99$ million in CAPDA-accredited ICT, plus R $\$ 44$ million in public ICT, also accredited by CAPDA.

Although the results of professional training programs do not have an immediate effect, with a medium-term view, this gap identified by Oliveira and Corrêa (2019) can be mitigated by actions provided for in the legislation. 


\section{B. Investment in RD\&I aimed at Industry 4.0}

According to the CNI (2018), $48 \%$ of Brazilian companies planned to invest in at least one of the digital technologies affected by industry 4.0 in 2018, however, a survey carried out in 2020 shows that direct effects of the Covid-19 pandemic frustrated investments forecasts, either by demand review or an unexpected increase in the cost of investing (CNI, 2021).

On the other hand, MFTZ industrial indicators show that computer goods manufacturing companies achieved growth, in 2020 , of $33.23 \%$ in sales in national currency (CIEAM, 2021), showing the inverse movement of the national industry on the capacity to perform investments.

Even though it is possible to allocate more than half of the investment obligation in RD\&I in projects developed by the factory itself, which would correspond to 297 million reais per year, considering the average of the last 5 years calculated in SUFRAMA (2021), the graph in Fig. 3 shows that only $15 \%$ were internally invested in this period. In this context, the then MDIC, current Ministry of Economy, published Ordinance No. 2091, of December 17, 2018, which, together with Resolution No. 40, of March 18, 2018, of the Board of Directors of Suframa (CAS), deal with investments in RD\&I aimed at industry 4.0 at MFTZ (Ordinance No. 2,091, 2018; Ordinance No. 2,145, 2018).

With the set of current standards and, knowing that Decree $10.251 / 2020$ allows projects with the theme of industry 4.0 to be carried out within the scope of the IL until 2028, there is an opportunity in the internal modality, based on the calculated average, of investments in the region of more than $\mathrm{R} \$ 2$ billion if companies start this movement in 2022 .

According to Ordinance No. 2091/2018, of the investment made to upgrade production lines for Industry 4.0, are eligible to use the resource of the application obligation in RD\&I arising from the IL, projects that aim to reach at least Stage 3 of maturity provided for in Schuh et al. (2020), which corresponds to Visibility in the scale shown in Fig. 4.

In the visibility stage, the cyber-physical system uses data, information and knowledge generated for computer simulations that can feed and contribute to the self-correction and self-optimization process, reducing the development cycle (Ordinance No. 2,091, 2018; Schuh et al., 2020).
The Resolution No. 40/2018/CAS innovated by allowing the allocation of the entire robot purchase price to projects classified as being in the industry 4.0 theme, as long as it does not exceed the limit of $40 \%$ of the project value (limit imposed by Ordinance No. 2,091/2018).

\section{Fostering the Innovation Ecosystem}

The involvement between government, business and academia defended by Reishauer (2018) in the form of the triple helix for innovation can, in a way, be seen in the operationalization of IL: the government defines the criteria for the use of the application obligation in RD\&I, companies choose projects and academia is one of the actors that can carry out these projects, whether in the form of training and qualification, or in carrying out $R \& D$.

One of the possible results of the triple helix defended by Reishauer (2018) is the formation of an innovation ecosystem which, according to Jackson (2011) is a cycle in which companies generate demand for new products (RD\&I), whose sales in the market will generate needs and resources for the creation of other new products. Along these lines, the same author theorizes that innovations generate businesses that, due to the nature of the resource path combined with inherent risks, result in the death of the vast majority, the reason for which is illustrated in Fig. 5.

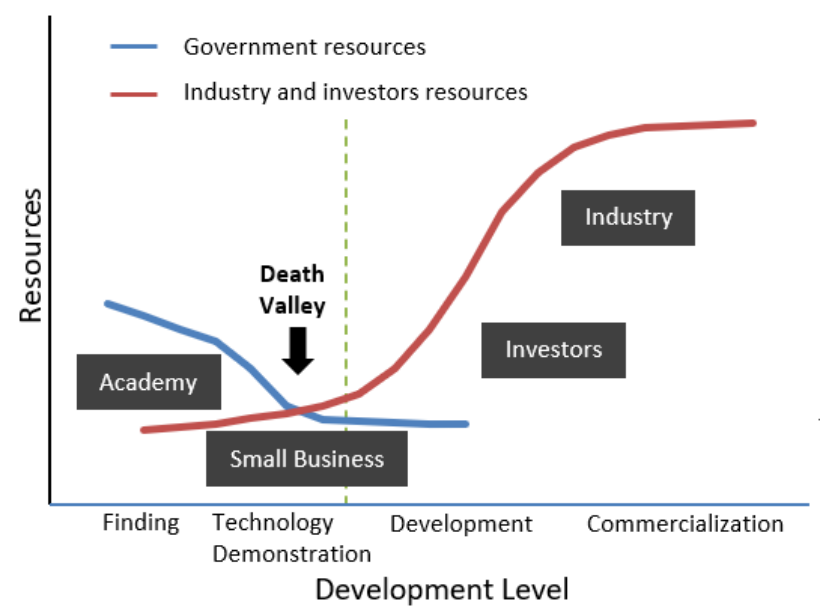

Fig. 5. An Innovation life graph (based on Jackson, 2011).



Fig. 4. Stages of Industry 4.0 Maturity (Adapted from Schuh et al. 2020). 
Fig. 5 shows that in the period in which the link with academia ends (end of R\&D), usually with government resources, when the MVP (Minimum Viable Prototype) is built, the startup has a minimum amount of resources, a fact that leads to the death of most of them (death valley).

In order to reduce this index so that the innovation ecosystem is more sustainable, the author suggests that the curves be shifted in order to reduce the valley of death as shown in Fig. 6.

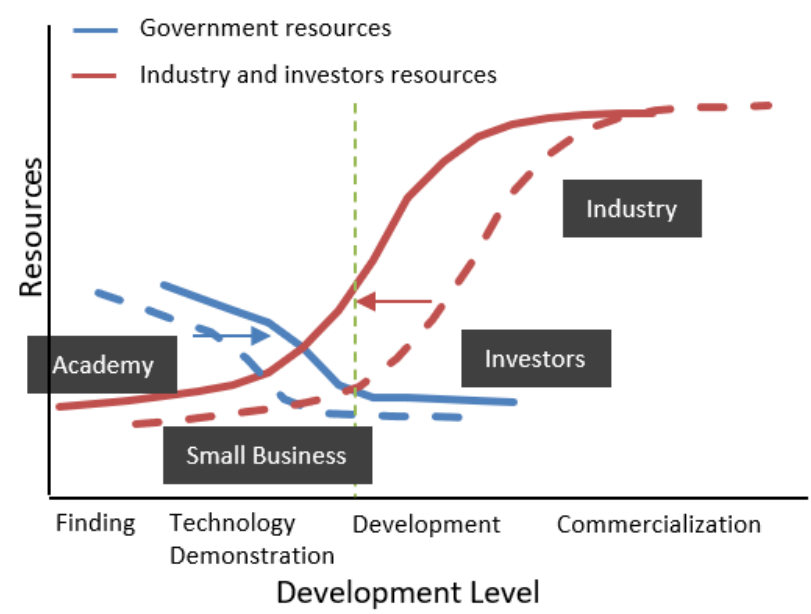

Fig. 6. Death Valley Mitigation (based on Jackson, 2011).

The displacement of the curves depicted in Figure 6, in the specific case of IL, will occur when companies invest in startups (shift of the orange curve to the left) giving support also to the academy (blue curve to the right).

Corroborating with this scenario, Rocha et al. (2019) affirm that startups are important players in the ecosystem that, in a context of open innovation, get connected with large companies in a collaborative environment to generate solutions in technology.

Such aspects can be explored by the IL beneficiary companies since 2018 when investments in projects involving technological innovation, including those for digital transformation, developed by startups became possible. That alternative was regulated by Ordinance No. 2,145, of $12 / 21 / 2018$, of the then Ministry of Industry, Foreign Trade and Services, current Ministry of Economy. In this normative instrument, the beneficiary company can invest in a startup, including the possibility to get equity participation in it, generating integration between the actors (Ordinance No. 2,145, 2018).

Indirectly, investments in startups can also be made through the Priority Programs, which, according to CAPDA (2019) are: Digital Economy, Bioeconomics, Innovative Entrepreneurship, and Human Resources Qualification.

\section{Opportunities and Challenges}

The digital transformation of companies towards industry 4.0 technologies, in regard to the most recent industrial revolution, which is still in its early stage, involves several fronts. This work studied three of them: (i) human resources qualification; (ii) RD\&I and (iii) entrepreneurship, linking the needs identified by the scientific literature with the possibilities that the normative set headed by IL offers to the RD\&I ecosystem at the MFTZ.
From the investment modalities allowed by IL expressed in Fig. 2, it is possible to estimate, based on the last 5 years of data presented by SUFRAMA (2021), from a conservative perspective of the trend presented by the computer goods industry installed in the MFTZ (Table I).

\begin{tabular}{|c|c|c|}
\hline$\%$ & Description & $\begin{array}{c}\text { Investment } \\
\text { until } 2028\end{array}$ \\
\hline 2,7 & $\begin{array}{l}\text { - R, D \& I activities carried out directly by the } \\
\text { company } \\
\text { - Investment in startups based in the Western } \\
\text { Amazon and Amapá }\end{array}$ & 2,079 \\
\hline 0,8 & $\begin{array}{l}\text { - Scientific and Technological Institute } \\
\text { accredited by CAPDA } \\
\text { - Priority Programs instituted by CAPDA }\end{array}$ & 616 \\
\hline 0,9 & $\begin{array}{l}\text { - Scientific and Technological Institute } \\
\text { accredited by CAPDA }\end{array}$ & 693 \\
\hline \multirow[t]{2}{*}{0,4} & $\begin{array}{l}\text { - Public Scientific and Technological Institute } \\
\text { accredited by CAPDA }\end{array}$ & 308 \\
\hline & TOTAL & 3,696 \\
\hline
\end{tabular}

As studied by Ghobakhloo (2018), the path to digital transformation must be designed based on strategic planning with long, medium, and long-term actions. To this end, it is necessary (i) financial resources, which have been extensively addressed by this work in the form of opportunity, as these are provided by a legal obligation; and, no less relevant, (ii) committed leadership, since investments in RD\&I, despite being compulsory in IL, the projects carried out are of the company's discretionary nature.

The document published in 2016 by FIRJAN, entitled: "Industry 4.0: Panorama of Innovation", highlights the fact that the Brazilian industry is still moving between the second and third industrial revolution, using assembly lines and the application of automation, as highlighted by Oliveira and Corrêa (2019).

In this sense, the development of industry 4.0 brings great challenges, which involve the use of the resources available by IL, in a convergence of interests of the triple helix presented by Reishauer (2018), which will help to overcome the challenges of the human resources qualifications, advanced manufacturing technologies and the creation of a thriving innovation ecosystem.

\section{CONCLUSION}

The general objective of this paper was to analyze the opportunities and challenges for the implementation of industry 4.0 from the perspective of public policy of RD\&I in the MFTZ. It was found that the phenomenon is presented as an ongoing revolution, reflected in the increasing digitalization and improvement of production processes, whose implementation, with a great socioeconomic impact, is projected as a challenge to the competitiveness of industries worldwide, including in the MFTZ. In this context, IL is presented as a tool that, through recent regulations, is aimed at supporting the adherence of the technologies of the fourth industrial revolution to industrial production processes.

It was identified that the resources involving IL in the MFTZ can be directed to investments in favor of increasing productive efficiency in advanced manufacturing and seem to indicate that public policy is looking for renewal to encourage the local implantation of industry 4.0 in the coming years. The 
developed legal framework has the possibility of prioritizing investments in essential components of the fourth industrial revolution, such as robotization, human resources qualification, software development, control hardware, and advanced sensors. Furthermore, the prospect of direct investment in technological and indirect innovation projects, through CAPDA's priority programs in startups, generates new possibilities of actors' connection with the demands of the industry in a collaborative environment of open innovation.

Despite this, it is evident the challenges imposed to a technological park created half a decade ago with a predominance of multinationals, which added to the need for complementary standards that guarantee the development of advanced manufacturing technologies in the MFTZ, IL must continue to evolve, requiring a strategic commitment by companies to use their application obligations in RD\&I following the correct propitious moment of technological changes to maintain competitiveness in the context of the transformation of industrial efficiency in the ZFM.

\section{REFERENCES}

Buhr, D. (2015). Social innovation policy for Industry 4.0. Berlin, Germany: Friedrich-Ebert-Stiftung.

CAPDA. (2019). Regulation No. 9, October 29, 2019. Diario Oficial da União, Brasilia, DF, 6 November 2019, No. 215, section 1, p. 159 , 2019. [Publication in Portuguese].

CIEAM. Indicadores Industriais ZFM. Available in $<$ https://cieam.com.br/ohs/data/docs/1/Apresentacao-IndicadoresIndustriais_Dezembro-2020-Site.pdf>. Accessed on 1 April 2021. [Publication in Portuguese].

CNI. Investimento em Indústria 4.0. Available in <https://static.portaldaindustria.com.br/media/filer_public/8b/0f/8b0f5 599-9794-4b66-ac83-

e84a4d118af9/investimentos_em_industria_40_junho2018.pdf>. Accessed on 1 April 2021. [Publication in Portuguese].

CNI. Investimento na Indústria 2020-2021. Available in $<$ https://static.portaldaindustria.com.br/media/filer_public/44/b0/44b0 1 acb-c442-4b11-8abc-

ca8f7a7e79c2/investimentosnaindustria_2020_2021.pdf >. Accessed in 1 April 2021. [Publication in Portuguese].

Etzkowitz, H. (2003). Innovation in innovation: The triple helix of university-industry-government relations. Social science information, 42(3), 293-337.

Federal Decree No. 10,521, October 15, 2020. Available in <http://www.planalto.gov.br/ccivil_03/_ato2019-

2022/2020/decreto/D10521.htm>. Accessed on 25 March 2021. [Publication in Portuguese].

Ferreira, V., \& Lisboa, A. (2019). Innovation and Entrepreneurship: From Schumpeter to Industry 4.0. In Applied Mechanics and Materials (Vol. 890, pp. 174-180). Trans Tech Publications Ltd.

FIRJAN. (2019). Indústria 4.0 no Brasil: Oportunidades, Perspectivas e Desafios. Available in https://www.firjan.com.br/publicacoes1/publicacoes-de-inovacao/industria-4-0-no-brasil-oportunidadesperspectivas-e-desafios.htm\#pubAlign. Accessed in 3 April 2021. [Publication in Portuguese].

FIRJAN. (2016). Indústria 4.0: panorama da inovação. Available in <https://www.firjan.com.br/publicacoes/publicacoes-deinovacao/industria-4-0-1.htm>. Accessed in 3 April 2021. [Publication in Portuguese].

Furtado, A. B. (2020). Como escrever Artigos Científicos, Dissertações e Teses. 3.ed. Belém: abfurtado.com.br. [Publication in Portuguese].

Gil, A. C. (2018). Como elaborar projetos de pesquisa. 6.ed. São Paulo: Atlas. [Publication in Portuguese].

Ghobakhloo, M. (2018). The future of manufacturing industry: a strategic roadmap toward Industry 4.0. Journal of Manufacturing Technology Management., 29, 910-936.

GTAI. (2014). Industrie 4.0. Smart Manufacturing for the Future. Available in <https://www.manufacturing-policy.eng.cam.ac.uk/documentsfolder/policies/germany-industrie-4-0-smart-manufacturing-for-thefuture-gtai/view>. Accessed on 5 April 2021.
Jackson, D. J. (2011). What is an innovation ecosystem. National Science Foundation, 1(2), 1-13.

Law No. 8,387, December 30, 19914. Informatics Law. Available in http://www.planalto.gov.br/ccivil_03/leis/18387.htm. Accessed on 25 March 2021. [Publication in Portuguese].

Data, I. I. (2005). Oslo Manual. Paris and Luxembourg: OECD/Euro-stat.

Oliveira, M. A. C., Mendes, D. R. F., Moreira, T. B. S., \& de Moura Cunha, G. H. (2015). Análise econométrica dos dispêndios em Pesquisa \& Desenvolvimento (P\&D) no Brasil. RAI Revista de Administração e Inovação, 12(3), 268-286. [Publication in Portuguese].

de Oliveira, S. S. B., \& Corrêa, E. M. (2019). TRABALHO E EDUCAÇÃO: algumas considerações sobre as mudanças no mundo do trabalho e a expansão do ensino superior da rede privada de Manaus/AM. Revista de Políticas Públicas, 23(2), 716-725. [Publication in Portuguese].

Ordinance No. 2,091, December 20, 2018. Ministry of Industry, Foreign Trade, and Services. Diario Oficial da União, Brasilia, DF, December 20, 2018, n. 244, section 1, p. 144-146. [Publication in Portuguese].

Ordinance No. 2,145, December 21, 2018. Ministry of Industry, Foreign Trade, and Services. Diario Oficial da União, Brasilia, DF, December 24, 2018, n. 246, section 1, p. 54. [Publication in Portuguese].

Pereira, A., \& de Oliveira Simonetto, E. (2018). Indústria 4.0: conceitos e perspectivas para o Brasil. Revista da Universidade Vale do Rio Verde, 16(1). [Publication in Portuguese].

Reischauer, G. (2018). Industry 4.0 as policy-driven discourse to institutionalize innovation systems in manufacturing. Technological Forecasting and Social Change, 132, 26-33.

Rocha, C. F., Mamédio, D. F., \& Quandt, C. O. (2019). Startups and the innovation ecosystem in Industry 4.0. Technology Analysis \& Strategic Management, 31(12), 1474-1487.

Schuh, G., Anderl, R., Dumitrescu, R., Krüger, A., \& Hompel, M. (2020). Industrie 4.0 maturity index. Managing the digital transformation of companies-Update 2020. acatech STUDY.

Schwab, Klaus. The Fourth Industrial Revolution. Ginebra: World Economic Forum, 2016.

SUFRAMA. (2021) Ministry of Economy. Distribuição dos Investimentos nas Modalidades (R\$ milhões). Available in <https://www.gov.br/suframa/pt-br/zfm/pesquisa-e-

desenvolvimento/lei-de-informatica/resultados>. Acessed in 25 March 2021. [Publication in Portuguese].

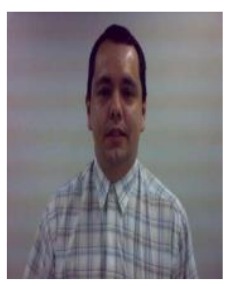

Armando Araujo de Souza Junior is a Business Administrator. He holds a Master's degree in Production Engineering from UFAM. He holds a $\mathrm{PhD}$ in Administration from the Federal University of Minas Gerais (UFMG).



Arthur de Freitas Lisboa was born in Belém, Brazil, in 1990. He achieved a bachelor degree in International Relations at the Amazon's University in 2012, as well as a M.B.A. in Management and International Business at International Universitary Centre in 2016. Lisboa is currently pursuing a master's degree in Production Engineering at the Amazonas Federal University, in Manaus, Brazil.



Luiz Frederico Oliveira de Aguiar was born in Manaus, Brazil, in 1987. He achieved a bachelor degree in Public Management at the Amazonas State University in 2008, as well as a M.B.A. in public policies and government management at International Universitary Centre in 2020. Aguiar is currently pursuing a master's degree in Production Engineering at the Amazonas Federal University, in Manaus, Brazil.

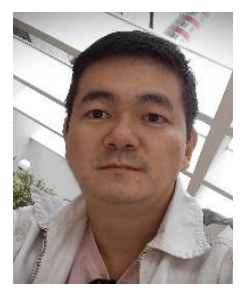

Mauricio Itikawa was born in Parana, Brazil, in 1978. He studied Electrical Engineering at University of Campinas in 2001 and is currently pursuing a master's degree in production engineering at Federal University of Amazonas. 
Ph.D. Ocileide Custodio da Silva is an associate Professor at the Technological Faculty Department of the Amazonas Federal University since 2010. She accomplished a Doctorate in Materials Engineering at the Polytechnic School of the São Paulo University in 2003. Previously, she achieved a master's degree in Chemical Engineering at São Carlos Federal University in 1997 and bachelor's degree in chemical engineering at Rio Grande do Norte Federal University in 1994, as well as diverse specializations such as Strategic Management of Technological innovation at Campinas State University in 2010 and Business Management at Paulist Institute of Teaching and Research in 1999.



Ph.D. Sandro Breval Santiago is an assistant professor at Amazonas Federal University. He is a postdoctoral fellow in Industry 4.0 at University of Port and, doctorate in Production Engineering at Santa Catarina Federal University. He has a master's degree in Production Engineering, specialization in Finance Management and graduation in Business Administration at Amazonas Federal University.

He has experience in a diverse segment of logistics and industry, performing $\mathrm{R} \& \mathrm{D}$ projects and is currently Technical Coordinator of Industry 4.0 Council at Manaus Economic, Sustainable, and Strategic Development Council (CODESE) and CTI Assistant Director at Amazonas State Industry Federation (FIEAM). 